\section{A COLTSFOOT PROBLEM}

\section{BY RICHARD MORSE}

$\mathrm{S}^{\mathrm{o}}$ OME time ago, when I was carrying out some $\checkmark$ investigations concerning the behaviour of plants, I came across the statement, in Sir J. E. Smith's "English Flora" (1829), that the flowers of the colts. foot (Tussilago farfara) are "drooping in the bud". The statement surprised me because, although I had been observing the behaviour of this plant fairly closely over a number of years, both in its wild state and under controlled conditions, I had never once seen it produce flower buds that could in any sense be called drooping. As it was inconceivable that the coltsfoot had changed its behaviour since 1829 I could only conclude that the great botanist was in error ; and there the matter was allowed to rest.

Recently, however, I have had occasion to inquire into the subject again, and have been amazed at the number of authors who have, in one form or another, repeated Sir J. E. Smith's statement-a statement which I still believe to be wholly untenable.

In Richard Deakin's monumental "Florigraphia Britannica" (1847), for example, the coltsfoot is described as having "the bud drooping, erect when in flower". Yet Deakin was, presumably, a careful worker with an extensive knowledge of British plants, for we are assured in his fourth volume that the entire series of illustrations, numbering well over 1,600, "are accurate facsimiles engraved from original drawings, made by the Author from the Plants themselves, and carefully coloured after nature".

Again, in the third volume of the five which Anne Pratt devoted to "The Flowering Plants and Ferns of Great Britain" (1856), reference is made to "the drooping unexpanded flower-buds" of this plant; in Hooker's famous "Student's Flora" (1884) appear the words "drooping in bud"; in Johns' "Flowers of the Field" (1919) the phrase takes the form of "drooping before expansion"; in Babington's "Manual of British Botany" (1922) the heads are spoken of as being "erect in blossom and seed, drooping before and after flowering" ; and in Macgregor Skene's "A Flower Book for the Pocket" (1935) occurs the similar statement that "the head droops in the bud and again after flowering".

The above books, it will be observed, cover the period 1829-1935, so that, during more than a hundred years, students of British botany have been asked to accept, in regard to one of our commonest native plants, a statement which, so far as my experience goes, has no foundation in fact, and yet which, so far as I know, has never been discussed or corrected-save for one brief reference that I myself made to it in a broadcast talk some years ago.

What makes the problem stranger still is the fact that several of the books I have mentioned have passed through more than one edition, without, so far as one can tell, any query being raised as to the correctness of the assertions made. Thus my quotations are taken from the second edition of Smith's "Flora", the third edition of Hooker's, the tenth of Babington's "Manual" (edited by A. J. Wilmott), and the thirty-fourth of Johns' "Flowers of the Field" (revised by G. S. Boulger).

Allusions to the coltsfoot's alleged habit of drooping its flower buds, moreover, are by no means confined to books of the more scientific flora type. They have crept also into our agricultural, educational and 'popular' botanical literature.
Thus in the Ministry of Agriculture's "Collected Leaflets on Weeds", second edition, 1923, we are told that "at first the flower heads droop, but when they open out they are erect" ; and H. C. Long, in his "Weeds of Arable Land"' (1929), uses precisely the same words.

Similarly, Prof. F. Cavers, in his "Life Histories of Common Plants" (1913)—a book intended chiefly for student teachers-tells us that each flower head "at first droops, but later becomes straight"; and in his more advanced work entitled "Botany for Matriculation", revised by L. C. Fox in 1931, those exact words are repeated.

In books of a less scientific character, written chiefly for the general public, the alleged drooping buds of the coltsfoot have been mentioned time and again, for although nutant flower buds are common enough in Nature, this particular story seems to have caught the popular imagination. In James Cundall's "Everyday Book of Natural History" (1866), for example, we read that "at first the flower bud is pendulous, and is thus protected from the rain; as soon, however, as the bloom is ready to unfold to the sun, the flower stalk becomes erect".

John J. Ward, in his "Life Histories of Familiar Plants" (1908), is even more explicit. "The coltsfoot," he says, "guards its pollen almost as a bird does its eggs. When at first the flower stem peeps above the soil, its head droops while the stem elongates. Then, suddenly, the head becomes erect and the florets are exposed."

Again, G. Clark Nuttall, in his fascinating sevenvolume work entitled "Wild Flowers as they Grow" (1912), tells us that, in February, the coltsfoot's "hard, thick stem with drooping head pushes up through the earth"; while Edward Step, in his "Spring Flowers of the Wild" (1927), says that "until the female florets are ready to open, the stem is bent, so that the head droops".

I must confess that I am much puzzled by the above and other similar references to what I believe to be a wholly fictitious phenomenon. At the time of writing I have no access to floras of a date earlier than Sir J. E. Smith's, so I am unable to say whether the belief in the coltsfoot's drooping flower buds goes back beyond his day or not.

Two possible explanations of the prevalence of the belief occur to me. One is that, after someone's original blunder, author has copied author through all these years without ever referring to the plant itself; and the other is that the closed fruit heads have been mistaken for unopened flower heads. The fruit heads do, of course, droop for a time after fertilization has taken place. They are, however, so markedly different in appearance from the flower buds that it seems almost incredible that even the veriest amateur could mistake one for the other.

But there is also, of course, the further possibility that my own observations of the plant are at fault. On that point, however, I must leave readers to judge for themselves.

Perhaps I should say, in conclusion, that the omission of several well-known floras from the above list must not be taken to mean that they have not been eonsulted, but simply that I have not yet found one that controverts the statement made by Sir J. E. Smith. There is no reference to the matter, for example, in Withering's "Arrangement of British Plants" (1830), or in Hooker and Arnott's "British Flora" (1850), or in Grindon's "British and Garden 
Botany" (1864), or in Bentham's famous "Handbook" (1924), or in Bonnier's "British Flora" (1925) or in any similar work to which $I$ have access. Brimble, in his "Flowers in Britain" (1944), does not query Smith's statement; but, though he refers to the flower heads being "borne at the ends of thick, erect stalks with hairy bracts", he does not state that the flower buds droop. Furthermore, an illustration shows an erect flower bud.

\section{THE BROAD TAPEWORMS OF MAN, CORMORANTS AND GULLS}

T. B. DUGUID and E. M. Sheppard (J. Path and Bact., 56,73 ; 1944. See also Nature, 154, 185 ; 1944) described their discovery of plerocercoids of a Diphyllobothriid tapeworm in freshwater trout and sticklebacks in a South Wales reservoir and their work on its life-history. M. D. Hickey and J. R. Harris (Brit. Med. J., 310, Sept. 2, 1944) also found Diphyllobothriid plerocercoids in trout in the Dublin area, and a Diphyllobothriid adult tapeworm in seagulls and cormorants there (see also M. D. Hickey, Brit. Med. J., 482, Oct. 7, 1944, and K. Unsworth, ibid., 385, Sept. 16, 1944). K. Unsworth (Ann. Trop. Med. and Parasit., 38, 213 ; 1944) has now published the results of his work on the life-history of the South Wales species.

Starting with a rat infested by Duguid and Sheppard, Unsworth was able to confirm the results obtained by them. He successfully infested the copepods Cyclops strenuus and Diaptomus gracilis, which Duguid and Sheppard also used, but found. that the former was the best first intermediate host. The nauplius larva of Cyclops readily ate the coracidia, which were fully developed by the time that the later copepod stages were reached. After 16-20 days of development in Cyclops, which Unsworth describes, the Cyclops were fed to sticklebacks, in which plerocercoids were obtained, chiefly in cysts on the serous surface of the stomach, under the peritoneum and under the liver capsule. When these sticklebacks were fed to one pike, which is known to be a second intermediate host of Diphyllobothrium latum of man, one plerocercoid was obtained from the pike. When plerocercoids from both the infested sticklebacks and the pike were fed to puppies aged $2-3 \frac{1}{2}$ months, the adult tapeworm developed in the puppies, which passed eggs in their fæces. Coracidia from these eggs infested Cyclops. Unsworth makes the interesting and epidemiologically important suggestion that the overwhelming infestation of the trout in so large an expanse of water in South Wales (100 per cent) was due to the fact that the trout ate sticklebacks which had already infested themselves by eating infested copepods. He supports this suggestion by the observation that the commoner fish hosts which harbour plerocercoids of Diphyllobothriid species (for example, perch, pike, wall-eyed pike, trout and burbot) are all fish-eating species, while the less common fish hosts of these plerocercoids (for example, grayling and pollan) eat fish only at times. Unsworth was unable to identify the species of Diphyllobothrium with which he was dealing, because he obtained only the scolex and immature anterior segments of the adult from the puppies which he experimentally infested; but, from these, he concluded that the South Wales species studied by him was too small to be D. latum of man. $\mathrm{He}$ was also able to infest puppies with plerocercoids sent to him by Hickey from the Dublin area, so that this Dublin species can apparently develop to maturity both in a mammal and in birds (gulls, herring gulls and cormorants). Unsworth concluded that the Irish species is not Diphyllobothrium latum of man. The immature stages are not, however, enough for the identification of species of Diphyllobothrium.

All these workers sent specimens of the adult tapeworms obtained by them to H. A. Baylis of the British Museum, who concludes (Brit. Med. J., 868, Dec. 30,1944 ) that all the tapeworms obtained from the gulls represented one species, and all those from the cormorants another. Comparison of the worms obtained from the experimental mammalian hosts by all the workers led Baylis to conclude that all the workers were dealing in their experiments with a single species, which is probably the old but littleknown species $D$. dendriticum (Nitzsch, 1824). In experimental mammalian hosts this species showed slight differences from species found in gulls, probably because the mammal is an abnormal host.

The question raised in the Lancet (475, April 8, 1944) that the species found in "South Wales might possibly be $D$. latum of man, which does occur in the west of Ireland (see below) and might possibly have been brought to Britain by Polish and Norwegian refugees, as it has been established endemically in North America by immigrants, would seem to have been negatived by Baylis's decision. The whole question, however, requires further investigation, for T. E. Gibson (Brit. Med. J., 200, Feb. 10, 1945) records yet another infestation of trout in a Northamptonshire reservoir with plerocercoids morphologically similar to those described by Duguid and Sheppard. These failed to infest a guinea pig, but they did infest three rats, which finally threw off the infestation spontaneously, as Unsworth's puppies did. Gibson also found plerocercoids "of a smaller type" in 40 per cent of "smaller fish" in the same reservoir, but attempts to infest rats with these have so far failed (see also T. Hare, Brit. Med. J., 347, March 10, 1945). In addition to this, Dr. Peterson of Yell informed Duguid and Sheppard that a species of Diphyllobothrium is also endemic among freshwater trout in some of the Shetland Islands.

With regard to the occurrence of Diphyllobothrium latum in man in west Ireland, N. O'Connor (Brit. Med. $J ., 737$, Dec. 2, 1944), discussing multiple infestation of man with two types of tapeworm, states that the existence in Ireland of $D$. latum of man was first recorded by O'Farrell (Lancet, i, 466, 1916 ; i, 570, 1918 ; and Irish J. Med. Sci., vi, 95; 1929). Another case was reported by O'Kelly (Irish J. Med. Sci., vi, 188 ; 1935). The first case of multiple infestation was recorded by O'Farrell (Irish J. Med. Sci., vi, $542 ; 1930)$. All these cases came from the Shannon area. O'Connor (loc. cit.) himself records the infestation of a husband and wife with D. latum in the River Erne area, near lakes not connected with the River Shannon, the wife's infestation being multiple and combined with infestation with Taenia saginata. Both ate perch, pike and eels, but no trout; the wife often ate undercooked meat and raw pork. The husband had never been abroad; the wife was born of Irish parents in Glasgow, which town she had visited only twice within the last twenty-three years. G. W. S. Andrews and A. C. Ogilvie (Brit. Med. J., 772, June 3, 1944) record a case of multiple infestation with Taenia saginata. G. LAPAGE. 